\title{
REYNOLD J. RUPPE
}

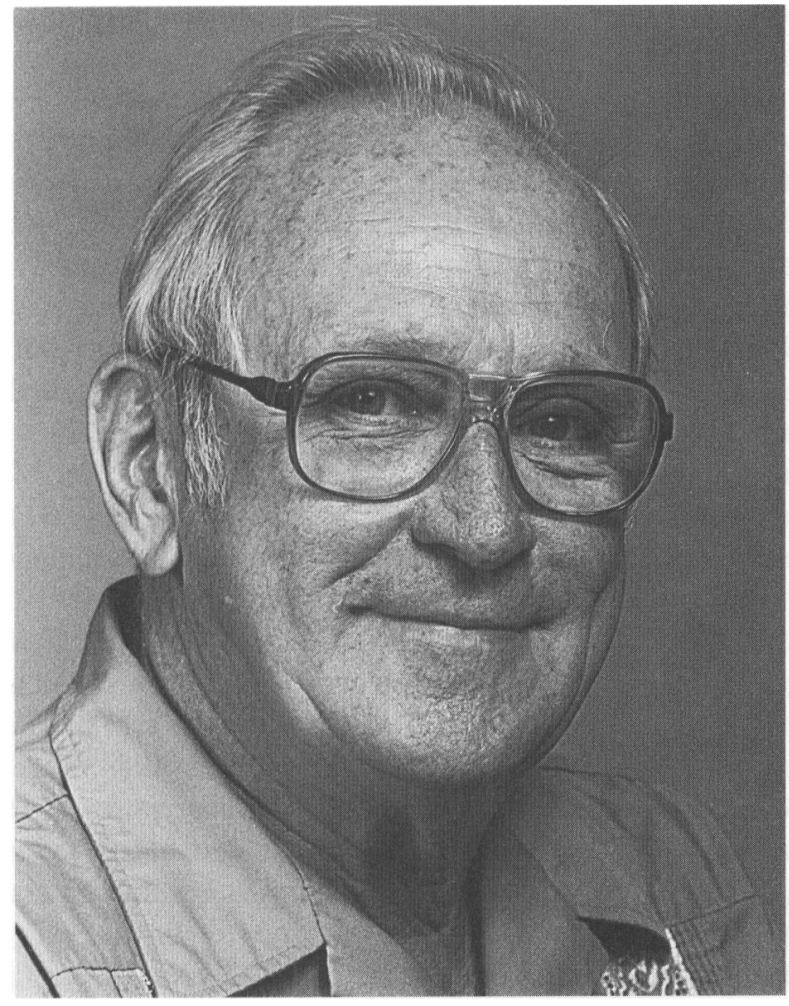

eynold J. Ruppé, professor emeritus in the Department of Anthropology at Arizona State University and that department's founding chair, died on Saturday, October 30, 1993, at his home in Tempe. He was 76 years old. More than any other single individual, Ruppé was responsible for establishing ASU's anthropology department and for creating and sustaining its nationally ranked graduate program.

The oldest of two children of Matilda Ann Onofrey and Reynold J. Ruppé, Rey was born on October 15, 1917, in Hellertown, Pennsylvania, and grew up in New Jersey. Originally trained in the ski troops, he served in World War II, during which he saw combat with the infantry in the European theater and was later assigned to the War Crimes Branch, where he was responsible for the interrogation of captured German officers (1943-1946). He received his formal education at the University of New Mexico (B.A. 1949) and at Harvard (Ph.D. 1953); both of his degrees were in prehistoric archaeology. After 
seven years on the faculty at the University of Iowa (1953-1960), during which time he was appointed the first Iowa state archaeologist (1955-1960), Ruppé was hired by ASU as chairman of its Department of Sociology and Anthropology. He arrived in 1960 to find himself the head of a troubled unit, riven by internal disputes and in need of direction. As a result of a statewide plebiscite and subsequent act of the state legislature and following years of bitter opposition by the partisans of the University of Arizona (Clark 1987), Arizona State College had just become Arizona State University.

A condition Ruppé placed on his acceptance of the appointment was that the combined department would eventually be separated into two autonomous units. The administration kept its promise, and a Department of Anthropology was created in 1962. Ruppé chaired the department from its inception until 1973, a period of unprecedented growth in faculty lines and in the development of its graduate programs, on which he had placed the highest priority. A master of arts was authorized in 1963, to be followed by a Ph.D. program in 1968. The anthropology program has, in the intervening years, become one of ASU's finest. As of this writing, 290 master's degrees, and 84 doctorates have been awarded, and ASU anthropology degree-holders are employed at some of the most prestigious research institutions in the country. In 1993, an SAA survey ranked the doctoral program in archaeology fourth in the nation.

Ruppé's involvement in archaeological research spanned more than four decades, beginning with excavations in Colorado in 1946, and continuing with fieldwork in New Mexico, Iowa, Arizona, and Florida. Ruppé made three major contributions to North American archaeology.

First, he conducted pioneering research in several regions of the American Southwest and Midwest that had received little attention by archaeologists before the 1940s and 1950s. With his long-time friend and colleague, A. E. Dittert, Ruppé surveyed, tested, and excavated pithouse villages and pueblo communities on Cebolleta Mesa, west-central New Mexico (1948-1952); this work formed the basis for his Ph.D. dissertation, awarded in 1953 (and published as a Garland "classic" in 1990). The research was significant for its early, innovative use of systematic survey methods, for its perspective on longterm culture change, spanning pre-pottery horizons to excavations at the modern Pueblo of Acoma, and for its close collaboration with the Acoma community - a collaboration that Dittert continues today (Dittert and Ruppé 1951, 1952; Ruppé 1953a; Ruppé and Dittert 1952, 1953).

During his tenure at the University of Iowa, Ruppé conducted ethnoarchaeological fieldwork among the Mesquakie Indians, and established a summer field school program in midwestern archaeology that investigated sites in western and southeastern Iowa (Ruppé 1953b, 1954, 1955a, 1955b, 1956, 1957, 1960). The latter work addressed the regional culture history of Iowa, especially the diverse range of prehistoric architectural features, ceramic types, and lithic assemblages found across the state. As the first Iowa state archaeologist, Ruppé was instrumental in developing early cultural resource management practices in the state.

Second, Ruppé contributed to making the archaeological survey a standard practice in North American fieldwork. In 1966 he published a seminal paper in American Antiquity titled "The Archaeological Survey: A Defense," in which he justified the importance of survey data to a wide range of research questions, and argued that it not only supplemented excavation data, but provided new kinds of information on regional-scale processes and demographic trends. The essay reflected his experiences in doing fieldwork in New Mexico, Iowa, and in the Salt River valley and on the Navajo Reservation in Arizona. Ruppé carefully considered different survey types and methods, including subsurface detection procedures, and the potential biases that result from the adoption of different survey strategies. Ruppé's publication proved to be very timely. A younger generation of archaeologists was rethinking the efficacy of traditional field methods in the American Southwest. Encouraged by Ruppés compelling defense of the problem-oriented survey as more than a simple prelude to excavation, Fred Plog and others developed survey strategies that specifically addressed "processual" questions on a regional scale, and advanced systematically designed surveys as an integral component of archaeological research designs.

Finally, Ruppé contributed to the study of coastal archaeology with his research on drowned terrestrial sites and sea level transgressions. The later years of his career were devoted to addressing the archaeological implications of post-Pleistocene eustatic rise on prehistoric coastal populations. 
Arguing for the early and intensive use of coastal habitats by foraging peoples, Ruppé hypothesized that inundated coastal settlements should be a common component of the underwater landscape of continental shelves (Ruppé 1978, 1980a, 1980b, 1981). In 1973, and continuing throughout the 1980s, he initiated an underwater archaeological research program in western Florida, where the broad, gently sloping shelf afforded ideal conditions for the preservation and detection of drowned sites. The 1973-1976 interval was spent excavating the Venice Beach Site, a shell midden located at depths of 1-2 $\mathrm{m}$ off the west coastal city of Venice (Lightfoot and Ruppé 1980; Ruppé 1980a). Subsequent research focused on survey methods for detecting other submerged settlements on the outer shelf. Ruppé's experiments with mechanical corers, side-scan sonar, and sub-bottom profilers eventually led to the discovery of 30 drowned sites in the vicinity of Venice Beach (Ruppé 1978, 1982, 1984, 1988). Ruppé was awarded a major National Science Foundation grant in 1986 to generate a catalog of subbottom profiler "signatures" for identifying specific kinds of underwater sites off the west Florida coast, depending on site structure, site constituents, and local marine geomorphology.

Although Ruppé will be remembered as the architect of ASU's anthropology department, and for his contributions to North American archaeology, perhaps his most enduring accomplishment was the guidance, motivation, and friendship he extended to countless students at the University of Iowa and Arizona State University. Ruppé's charismatic personality could inspire even the most skeptical graduate student to recognize the importance of regional survey, or excite an undergraduate to register for a course on underwater archaeology in land-locked Arizona! His door was always open to students and colleagues alike. This junior author remembers fondly late afternoons with Ruppé, when-one-byone-students would slip into his office. In his Johnny Carson persona, he would ask us to "move down the couch" to make room for the next visitor, who had come to seek advice from the "grand old man."

Ruppe retired in 1985 and in 1987, on the occasion of the 25th anniversary of the founding of the department, a volume of essays by 25 former students, friends, and colleagues was published to honor him (Gaines 1987). Called Coasts ,Plains and Deserts, it reflected the three aspects of Ruppé's archaeological research career- "coasts" referring to his longstanding interest in underwater archaeology, "plains" to his early work in Iowa, and "deserts" to the southwestern research with which he was involved both before and after his arrival at ASU. The fetschrift is testimony to the high regard with which he was held by the profession. As an active researcher, Ruppé was a member or a fellow of many learned societies, including the American Association for the Advancement of Science, the American Anthropological Association, the Society for American Archaeology, the Society for Historical Archaeology, and the International Oceanographic Foundation. He served on the editorial boards of a number of journals and was a long-time member of the Board of Trustees of the Heard Museum (1967-1980).

Ruppé is survived by his wife of 49 years, Carol Ruppé; daughter, Tricia Ruppé Durden; son, Larry Ruppé; grandson, Reynold Ruppé Durden, granddaughter, Georgia Carolyn Durden; and sister, Matilda Ann Ruppé. Memorials can be made to the Ruppé Prize in Archaeology, care of the ASU Foundation, Arizona State University, Tempe AZ 85287-0904.

Geoffrey A. Clark AND Kent G. Lightfoot

\section{Select Bibliography of and about Reynold J. Ruppé}

Clark, G. A.

1987 Reynold J. Ruppé and the Department of Anthropology at Arizona State University (1962-1987). In Coasts, Plains and Deserts: Essays in Honor of Reynold J. Ruppé, edited by S. W. Gaines, pp. 1-9. Anthropological Research Papers No. 38. Arizona State University, Tempe.

Dittert, A. E., and R. J. Ruppé

1951 The Archaeology of Cebolleta Mesa: A Preliminary Report. El Palacio 58(4):116-129.
1952 The Development of Scientific Investigation of the Cebolleta Mesa Area, Central-Western New Mexico. Kiva 18:13-18.

Gaines, S. W. (editor)

1987 Coasts, Plains and Deserts: Essays in Honor of Reynold J. Ruppé. Anthropological Research Papers No. 38. Arizona State University, Tempe.

Lightfoot, K. G., and R. J. Ruppé

1980 Oyster carrying capacity at Venice, Florida, Two Thousand Years Ago. Bulletin of the Bureau of Historic Sites and Properties 6(1):47-60.

Ruppé, R. J.

1953a The Acoma Province: An Archaeological 
Concept. Unpublished Ph.D. dissertation, Department of Anthropology, Harvard University, Cambridge, Massachusetts.

1953b The Present Status of Iowa Archaeology. Journal of the Iowa Archaeological Society 3(2-3):16-24.

1954 An Archaic Site at Olin, Iowa. Journal of the Iowa Archaeological Society 3(4):12-15.

1955a The Earliest Indians of Iowa. The Iowan $3(4): 24-27$

1955b The Woodland Indians of Iowa. The Iowan 3(5): 16-19, 47.

1956 Iowa Archaeology. Journal of the Iowa Archaeological Society 5(1):2-17.

1957 An Occurrence of Marion Thick Pottery in Iowa. Newsletter of the Iowa Archaeological Society 23:5-6.

1960 The Westwood Site: A Middle Woodland Burial Mound. Journal of the Iowa Archaeological Society 9(3):20-22.

1966 The Archaeological Survey: A Defense. American Antiquity 31:313-333.

1978 Underwater Site Detection by Use of a Coring Instrument. In Beneath the Waters of Time: Proceedings of the Ninth Conference on Underwater Archaeology, edited by J. B. Arnold, pp. 119-121. Publication No. 6. Texas Antiquities Committee, Austin.

1980a The Archaeology of Drowned Terrestrial Sites. Bulletin of the Bureau of Historic Sites and Properties 6(1):35-45.

$1980 \mathrm{~b}$ Sea-Level Rise and Caribbean Prehistory. In Proceedings of the Eighth International Congress for the Study of the Pre-Columbian
Cultures of the Lesser Antilles, edited by S. Lewenstein, pp. 331-337. Anthropological Research Papers No. 22. Arizona State University, Tempe.

1981 Sea Level Change as a Variable in Colonial American Archaeology. In The Realms of Gold: Proceedings of the Tenth Conference on Underwater Archaeology, edited by W. A. Cockrell, pp. 195-201. Fathom Eight Publications, San Marino, California.

1982 An Assessment of Cultural Resource Surveys on the Outer Continental Shelf. Bureau of Land Management, U.S. Department of the Interior, New Orleans.

1984 Geophysical Remote Sensing as an Aid to Underwater Site Survey. In Proceedings of the Thirteenth Conference on Underwater Archaeology, edited by D. Keith, pp. 47-50. Fathom Eight Publications, San Marino, California.

1988 The Location and Assessment of Underwater Archaeological Sites. In Wet Site Archaeology, edited by B. A. Purdy, pp. 55-68. Telford Press, Caldwell, New Jersey.

1990 The Acoma Culture Province: an Archaeological Concept. Garland Publishing, New York.

Ruppé, R. J., and A. E. Dittert

1952 The Archaeology of Cebolleta Mesa and Acoma Pueblo: A Preliminary Report Based on Further Investigation. El Palacio 59(7):191-217.

1953 Acoma Archaeology: A Preliminary Report on the Final Season in the Cebolleta Mesa Region, New Mexico. El Palacio 60(7):259-273. 